\title{
SISTEM PEMBAYARAN RINCIAN BIAYA KULIAH PADA PERGURUAN TINGGI RAHARJA MENGGUNAKAN GO+
}

\author{
Ageng Setiani Rafika ${ }^{1}$ \\ Deviana Ika Putri ${ }^{2}$ \\ Siskawati Sanusi ${ }^{3}$ \\ Dosen Sistem Komputer STMIK RAHARJA ${ }^{1}$, Mahasiswa STMIK RAHARJA ${ }^{2,3}$ \\ Jl Jenderal Sudirman no.40, Modern, Cikokol Tangerang ${ }^{1,2,3}$ \\ Email : agengsetianirafika@ raharja.info ${ }^{1}$, deviana.ika@ raharja.info ${ }^{2}$, siskawati@ raharja.info ${ }^{3}$
}

\begin{abstract}
ABSTRAK
Seiring perkembangan teknologi digital yang semakin canggih, sistem pembayaran online marak dipergunakan baik di instansi pemerintah maupun swasta. Begitu pula pada Perguruan Tinggi. Financial Accounting System pada Perguruan Tinggi Raharja yang di sebut GO (Green Orchesta) dikatakan masih belum menggunakan metode yang efektif dan efisien karena mahasiswa diharuskan datang ke kampus terlebih dahulu untuk mengetahui beberapa tagihan yang harus di bayar. Bahkan untuk mengetahui RBR (Rincian Biaya Registrasi) dan RBK (Rincian Biaya Kuliah) masih memakai jaringan lokal yang hanya dapat di akses pada BoxSiS (Student iLearning Service Box). Dengan pesatnya teknologi yang ada, sistem GO (Green Orchesta) perlu dibuatkan pembaruan dengan versi onlinenya yang mampu di akses kapanpun dan dimanapun oleh mahasiswa. Maka dari itu munculah sistem yang telah diperbarui yaitu GO+ (Green Orchestra Plus). GO+ (Green Orchestra Plus) mempermudah semua sistem pembayaran pekuliahan mahasiswa seperti mahasiswa dapat mengecek rincian biaya perkuliahan dimana saja dan kapan saja. Tidak hasrus datang kekampus dan antri di box sis. GO+ (Green Orchestra Plus) sangat efisien dan efektif untuk digunakan karena dapat menunjang proses pembayaran secara online.
\end{abstract}

Kata kunci: Green Orchesta (GO), GO+ (Green Orchestra Plus), efektif, efisien, online.

\begin{abstract}
Along with the development of increasingly sophisticated digital technology, online payment system rife used both government and private agencies. Similarly, in Higher Education. Financial Accounting System on Higher Education Prog is called GO (Green orchesta) is said to be still using the method of effective and efficient because students are required to come to campus first to find out some of the bills that must be paid. Even to know RBR (details Registration Fees) and Yandex (details Tuition) still use the local network that can only be accessed on BoxSiS (Student iLearning Service Box). With the rapid development of existing technologies, systems GO (Green orchesta) need to be made updates to the online versions are able to be accessed anytime and anywhere by students. Hence comes the system that has been updated is GO + (Green Orchestra Plus). GO + (Green Orchestra Plus), enables all payment systems pekuliahan student as the student can check the details of tuition anywhere and anytime. Not hasrus come kekampus and queued at the box sis. GO + (Green Orchestra Plus) highly efficient and effective for use as it can support the process online payments.
\end{abstract}

Keywords: Green orchesta (GO), GO + (Green Plus Orchestra), effective, efficient, online. 


\section{PENDAHULUAN}

Sistem Pembayaran yaitu sistem yang mencakup segala aturan, lembaga dan mekanisme. [1] Fungsi sistem tersebut digunakan untuk memenuhi suatu kewajiban yang timbul dari suatu kegiatan transaksi pada dunia pendidikan. Sistem Pembayaran berkaitan dengan pemindahan sejumlah nilai uang dari satu pihak ke pihak lain. Media yang digunakan untuk pemindahan nilai uang tersebut banyak macamnya, mulai dari penggunaan alat pembayaran yang sederhana sampai pada penggunaan sistem yang kompleks. Sistem Pembayaran tersebut terbagi menjadi dua, yakni sistem pembayaran tunai dan sistem pembayaran non tunai. Suatu metode yang dapat digunakan oleh para mahasiswa dalam proses pembayaran perkuliahan yakni dengan datang ke kampus dan menanyakan perihal biaya tagihan yang harus dibayar. Metode pembayaran tersebut merupakan suatu metode pembayaran secara umum digunakan dimana mahasiswa lebih mudah dan tidak membuang waktu. Namun setiap metode pasti ada kelebihan dan kelemahannya.

Dalam perkembangan zaman yang sangat canggih ini metode pembayaran ada dua yakni metode dalam pembayaran online dan offline. Banyak khalayak umum sudah tidak asing lagi mendengar apa itu definisi pembayaran online ataupun offline. Online merupakan sebuah istilah dimana kita sedang atau sudah terhubung dengan internet dalam dunia maya dengan sebuah koneksi. Sedangkan offline mempunyai istilah tidak terhubungan dengan internet atau manual. Alat pembayaran yang menggunakan teknologi tinggi dimana transaksi sering kali dilakukan oleh pihak-pihak yang memiliki jarak jauh, sehingga mau tidak mau menggnakan teknologi sebagai alat pembayarannya disebut dengan alat pembayaran online. Meskipun begitu tidak semua alat pembayaran mutlak menggunakan teknologi yang canggih atau menggunakan alat pembayaran online. Beberapa alat pembayaran yang offline dan sejak dahulu sudah dipraktikan serta sering digunakan yaitu pembayaran secara tunai (kontan), cek, wesel, dan emas. Saat ini, cara pembayaran di Perguruan Tinggi Raharja masih manual. Dimana mahasiswa harus log in pada box sis untuk melihat rincian biaya yang harus dibayar. Untuk log in pada box sis maka mahasiswa harus antri, karena box sis yang ada hanya ada 3 box yang harus melayani ribuan mahasiswa. Apalagi ketika sudah mendekati jatuh tempo pembayaran, antrian di box sis bisa mencapai 1 meter, hal ini tidak efisien dan efektif karena dapat menyita waktu yang cukup lama. Tidak berhenti disini, setelah mendapatkan rincian biaya perkuliahan, mahasiswa harus kembali menghadapi antrian yang panjang dikasir untuk membayar tagihan yang tertera. Dikasir, selain antri, proses yang ada juga cukup lama karena manual didalam prosesnya si kasir harus menginput data, menghitung uang dan mengsi tanda tangan. Loket yang ada pun tidak memadai hanya ada 2 loket. Informasi pembayaran tidak tersosialisasikan dengan baik, dikarenakan pengumuman pembayaran diinformasikan melalui email Rinfo hanya saat semester pertama. Setelah itu, mahasiswa Perguruan Tinggi Raharja tidak lagi mendapatkan notifikasi email Rinfo pembayaran. Oleh karena itu, Mahasiswa Perguruan Tinggi Raharja harus mengecek perincian biaya kuliah selanjutnya melalui (Student iLearning Service Box) BoxSis ataupun menanyakannya pada kasir. Adapun pengertian dari BoxSIS ialah sebuah mesin yang berbentuk persegi yang masih menjadi unggulan di Perguruan Tinggi Raharja untuk proses akses mahasiswa mengenai form perkuliahan dan melihat daftar nilai.

Berikut gambar yang menggambarkan antrian di Box sis dan kasir untuk melihat rincian dan membayar tagihan mahasiswa. 


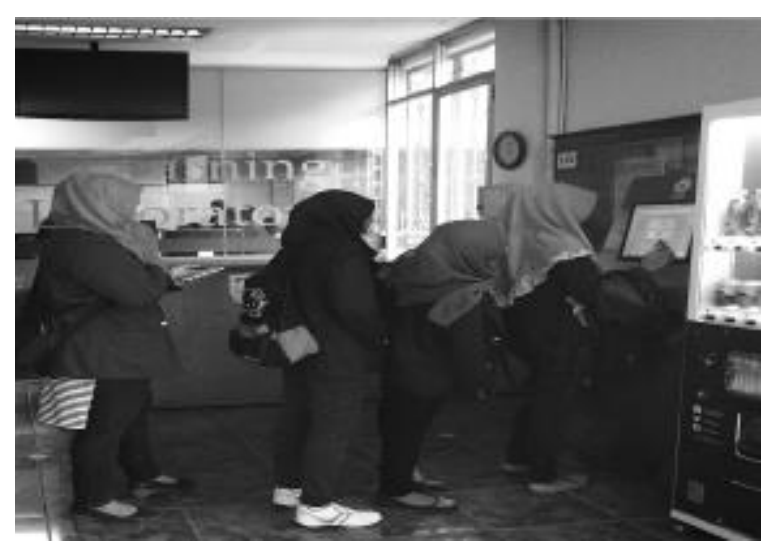

Gambar 1. Antrian di BoxSiS

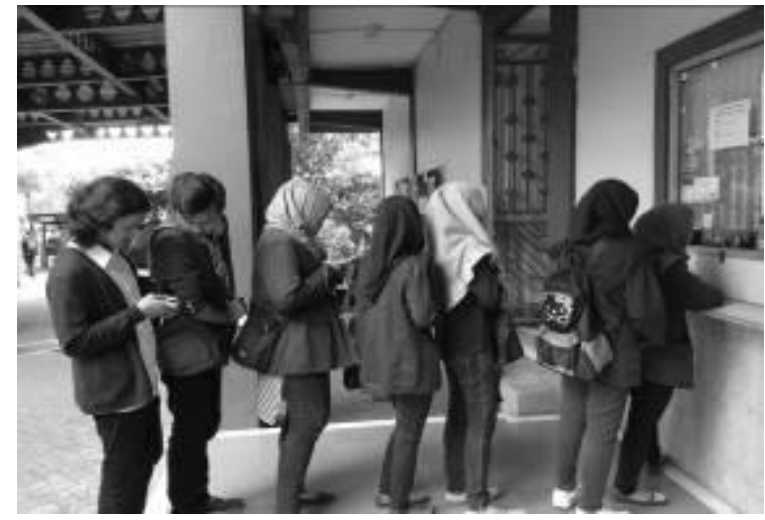

Gambar 2. Antrian di Kasir

Hal yang terjadi saat ini dalam proses pembayaran tagihan perkuliahan sangat tidak efesien dan efektif serta memakan waktu yang lama. Oleh karena itu, Penulis dalam pembuatan jurnal ini mengangkat tema pembayaran dengan judul SISTEM PEMBAYARAN RINCIAN BIAYA KULIAH PADA PERGURUAN TINGGI RAHARJA MENGGUNAKAN GO+.

\section{METODE PENELITIAN}

Setiap hari transaksi pembayaran selalu terjadi, pembayaran-pembayaran ini terjadi karena adanya bermacam-macam transaksi ekonomi seperti jual beli barang dan jasa, pembelian dan pelunasan kredit, alat pembayaran yang digunakan bermacam-macam antara lain :

1. Tunai

2. Cheque

3. Bilyet Giro

4. Wesel Dll

Pembayaran adalah suatu tindakan menukarkan sesuatu ( uang/barang) dengan maksud dan tujuan yang sama yang dilakukan oleh dua orang atau lebih. Sistem pembayaran dibedakan menjadi dua yaitu :[2]

1. Pengertian Pembayaran Tunai Pembayaran tunai atau yang biasa disebut dengan pembayaran cash, merupakan pembayaran atas harga barang atau jasa secara tunai, dimana pihak pembeli menyerahkan uang sebagai bukti pembayaran sebesar harga barang yang dibeli bersamaan dengan surat pesanan. Pembayaran tunai ini biasanya dilakukan dengan menggunakan uang tunai. Instrumen pembayaran tunai adalah uang kartal yang terdiri dari uang kertas dan uang 
logam.

2. Pengertian Pembayaran Non TunaiPembayaran non tunai adalah pembayaran yang dilakukan dengan cara:

a. Bayar dimuka yaitu pembayaran harga sebelum barang diterima atau sebelum barang ada.

b. Bayar dibelakang, yaitu pembayaran yang dilakukan dalam jangka waktu tertentu setelah barang diterima.

c. COD (cash on delivery), dimana pembayaran dilakukan pada waktu barang diserahkan pada pembeli, dan ada pula yang pembayaran dilakukan pada waktu dokumen tiba.

Instrumen pembayaran non tunai dapat dibagi atas alat pembayaran non tunai dengan media kertas, seperti cek, bilyet giro, wesel, dll, serta alat pembayaran non tunai dengan media kartu (plastic money) seperti: kartu kredit, kartu debit, kartu ATM, dll. Dengan demikian,mkarena adanya cara pembayaran tunai atau kartu kredit tsb, maka transaksi pembelian dan penjualan dapat dibedakan menjadi: pembelian tunai, pembelian kredit (non tunai), penjualan tunai dan penjualan kredit (non tunai).[2]

Pembayaran adalah berpindahnya hak pemilikan atas sejumlah uang atau dan adari pembayar kepada penerimanya, baik langsung maupun melalyui media jasa-jasa perbankan[3]. Dalam hal ini perlu ditegaskan bahwa pembayaran bukanlah sebagai suatu proses yang berdiri sendiri, yan terjadi secara spontan tanpa ada kaitannya dengan transaksi lain, sebab setiap pembayaran merupakan pelaksanaan atau realisasi dari suatu transaksi ekonomi.

Informasi yang cepat dan akurat sangat diperlukan dalam zaman yang pesat ini Guna menunjang keperluan dan kebutuhan yang selalu membutuhkan informasi yang cepat dan akurat. Informasi adalah hasil dari pengolahan data dalam suatu bentuk yang lebih berguna dan lebih berarti bagi penerimanya yang menggambarkan suatu kejadian - kejadian (event) yang nyata (fact) yang digunakan untuk pengambilan keputusan[4]. Informasi dalam lembaga pendidikaan seperti Perguruan Tinggi Raharja pun sama pentingnya untuk memberikan fasilitas yang memadai. Salah satu informasi yang dibutuhkan dalam pendidikan adalah informasi tagihan rincian biaya perkuliahan. Dalam penelitian sebelumnya informasi rincian biaya kuliah hanya bisa dilihat di lokal dan hanya bisa menggunakan Box Sis.[5]

Dalam tiap semester mahasiswa/i harus datang ke kampus untuk melihat perincian biaya kuliah di (Student iLearning Service Box) BoxSis. Terkadang ada pula mahasiswa yang lupa berapa pembayaran tersebut sehingga mengharuskan mahasiswa untuk menanyakannya kembali melalui kasir. Dengan ini mahasiswa harus memberi Kartu Tanda Mahasiswa yang dikenal dengan Pribadi Raharja Card (PRC) untuk mengetahui jumlah jatuh tempo pembayaran kuliah.

Pribadi Raharja Card (PRC) adalah kartu identitas diri yang diberikan kepada mahasiswa baru yang telah memenuhi semua persyaratan sebagai mahasiswa[6]. 


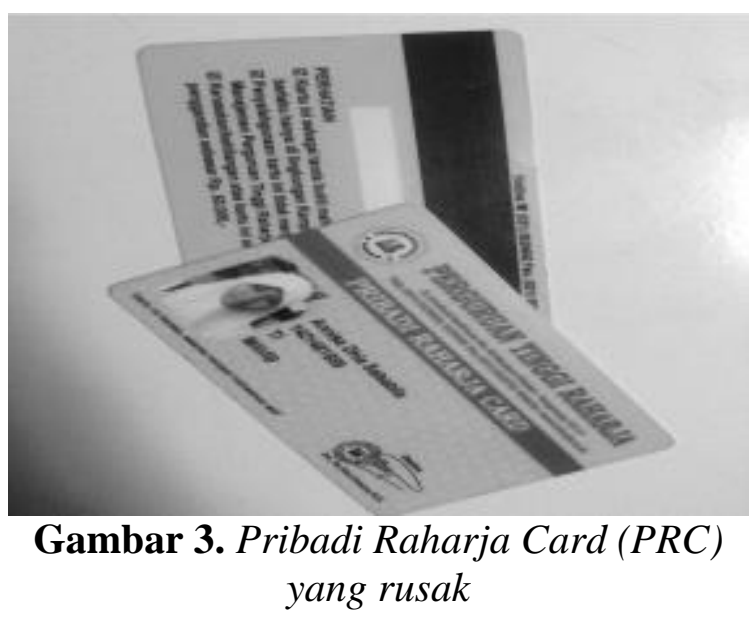

Kendala yang sering muncul saat menggunakan PRC selain antrian yang panjang pada BoxSis adalah kartu Pribadi Raharja Card (PRC) mahasiswa yang rusak, kerusakan dapat terjadi saat penggesekan kartu maupun hal yang tak terduga lainnya seperti tiba-tiba tidak berfungsi dengan semestinya dan harus konsultasi dengan penjaga kasir.

Loket kasir yang terlalu sedikit pada Perguruan Tinggi Raharja belum dapat secara maksimal melayani seluruh mahasiswa perihal perincian biaya kuliah atau juga tentang kendala kerusakan kartu, yang mengakibatkan antrian yang panjang. Hal tersebut menjadi tidak efektif bagi mahasiwa/i Perguruan Tinggi Raharja yang cenderung menjadi pemborosan waktu dikarenakan terlalu lama dalam antrian yang tak terduga.

Metode Green Orchesta Plus (GO+) dibuat untuk mempermudah pembayaran bagi mahasiswa. Dimana setelah membuka Green Orchesta Plus (GO+) tersebut mahasiswa Perguruan Tinggi Raharja dapat mengetahui berapa tagihan yang harus dibayar dan berapa tagihan yang sudah dibayar yang bisa memberikan kemajuan pada aspek bidang teknologi. Green Orchesta Plus $(\mathrm{GO}+)$ merupakan metode yang cukup efektif dan efisien untuk digunakan, sehingga sangat baik untuk menunjang proses pembayaran khususnya bagi Mahasiswa Perguruan Tinggi Raharja.

Berikut gambar Halaman Utama pada Green Orchesta Plus (GO+)

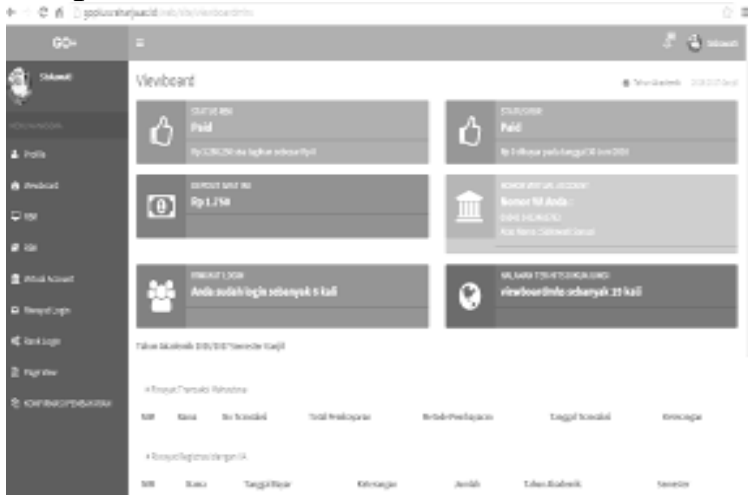

Gambar 4. Halaman utama pada Green Orchesta Plus (GO+)

Dalam proses pembayaran tersebut merupakan media yang terpublish untuk mahasiswa Perguruan Tinggi Raharja dalam penggunaan untuk mengetahui beberapa pembayaran yang harus dibayar dan berapa pembayaran yang sudah dibayar. Metode ini merupakan media ter- 
update dan selalu mengalami peningkatan yang cukup signifikan. Salah satu sarana yang memanfaatkan teknologi internet sebagai sarana distribusi informasi. Dengan menggunakan teknologi internet, Green Orchesta Plus (GO+) sangat mudah untuk diakses dimana saja dan kapan saja.

Dengan adanya notifikasi sistem pembayaran yang telah diberikan dapat digunakan untuk melakukan pembayaran dengan menggunakan Green Orchesta Plus $(G O+)$, selain praktis Green Orchesta Plus $(G O+)$ pun lebih menghemat waktu, jika lupa pembayaran biaya jatuh tempo perkuliahan maka bisa kapan saja mengecek kehalaman website GO+, disiplin waktu dalam pembayaran. Sehingga mahasiswa/i lebih mudah dan tidak membuang-buang waktu dalam kegiatan antri-mengantri juga lebih tepat waktu untuk melakukan transaksi pembayaran perkuliahan. Green Orchesta Plus $(G O+)$ mempunyai fitur-fitur unik yang didalamnya terdapat fitur pendukung, selain berisi text mahasiswa/i pun bisa melihat riwayat login serta rank login dari seluruh mahasiswa/i Perguruan Tinggi Raharja, terdapat juga Profil mahasiswa, Viewboard, RBR, RBK, Vitual Account, Page View dan Konfirmasi Pembayaran. Fitur ini sangat membantu proses transaksi pembayaran sehingga mahasiswa/i tidak bosan jika mengunjungi site yang telah dimiliki. Dengan menggunakan Green Orchesta Plus $(G O+)$ staff keuangan dan kasir dapat mengetahui siapa saja mahasiswa/i yang sudah membayar biaya perkuliahan pada semester tersebut. Semua mahasiswa Perguruan Tinggi Raharja dapat menggunakan Green Orchesta Plus $(G O+)$. Membuka website tersebut harus memiliki koneksi internet dan iPad atau Handphone untuk menjalankan aktivitasnya pada saat pengecekan biaya.

Rincian Biaya Register (RBR) adalah salah satu menu utama untuk mengetahui berapa tagihan perkuliahan yang harus dibayar. Biasanya Rincian Biaya Register (RBR) dilakukan saat pembayaran awal semester untuk mahasiswa baru di Perguruan Tinggi Raharja.[7]

Sedangkan untuk Rincian Biaya Kuliah (RBK) adalah untuk mengetahui tagihan pembayaran perkuliahan mahasiswa pada saat jatuh tempo setiap per semester.[7]

Berikut ini adalah gambaran dalam membuka Green Orchesta Plus $(G O+)$ agar mahasiswa/i bisa lebih memahaminya. 


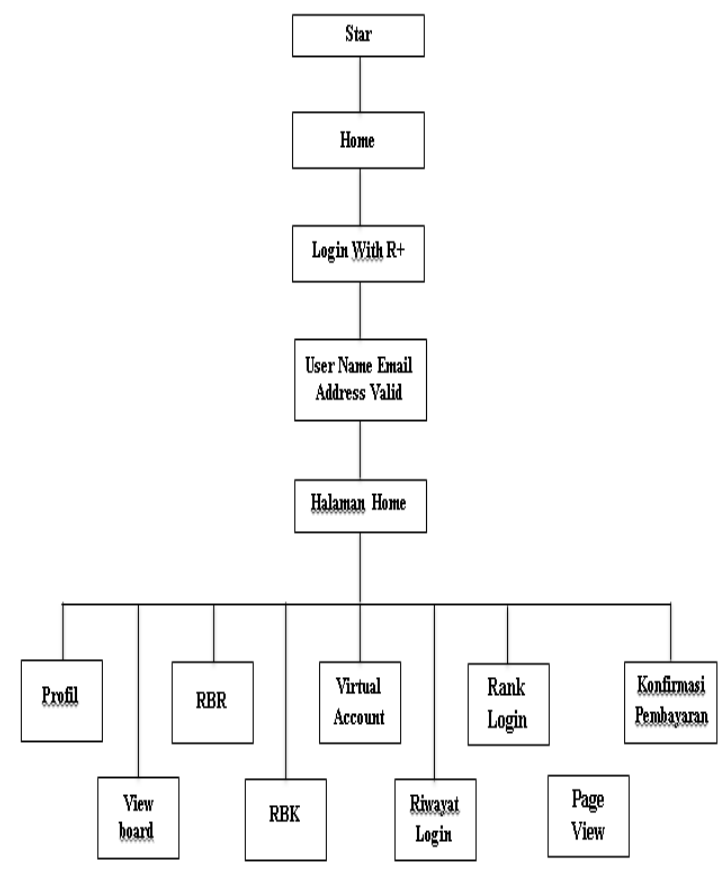

Gambar 5. Skema Login pada GO+

Gambar diatas menjabarkan proses log in mengggunakan Rinfo pada Green Orchesta Plus $(G O+)$, ketika email akun sudah valid maka akan diarahkan ke halaman utama pada Green Orchesta Plus (GO+). Setelah berhasil masuk mahasiswa bisa memilih tools tools yang diinginkan.

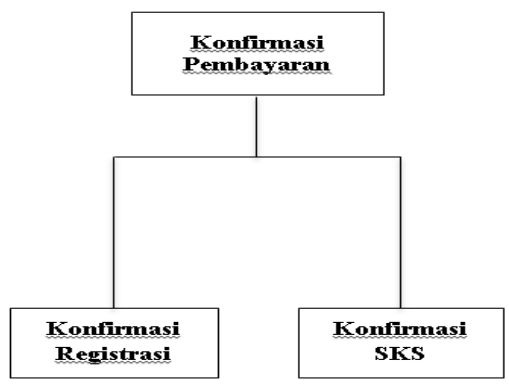

Gambar 6. Menu Konfirmasi Pembayaran

Gambar diatas merupakan tools dari konfirmasi pembayaran dimana mahasiswa bisa mengupload bukti atau struk yang telah diberikan oleh pihak bank.

\section{HASIL DAN PEMBAHASAN}

Manfaat Green Orchesta Plus (GO+) antara lain:

a. Pembayaran Jarak Jauh

b. Menghemat Waktu

c. Memudahkan dalam pembayaran

d. Memberikan rincian yang detail

Tampilan website Green Orchesta(GO+) mempunyai banyak fitur yang dapat digunakan oleh 
mahasiswa yang terdiri dari:

a) Halaman Utama

Website tersebut dapat di akses di luar kampus oleh mahasiswa dengan menuju alamat website goplus.raharja.ac.id[5]

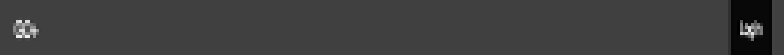

$\ln \ln$

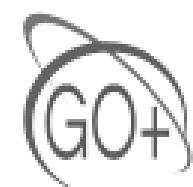

8

son:se

Gambar 7. Tampilan halaman utama

b) Login pada website Green Orchesta Plus (GO+) dengan Rinfo

Seperti website lainnya adanya login untuk masuk ke dalam website agar bisa melihat rincian Biaya Kuliah.

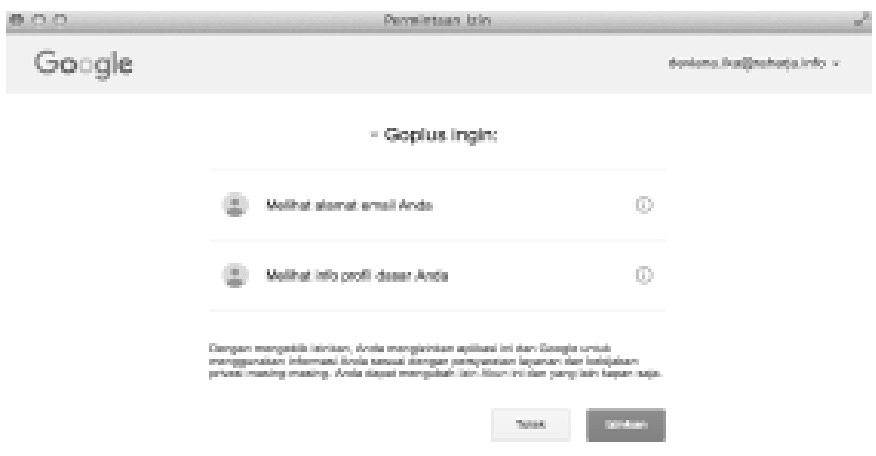

Gambar 8. Tampilan Login website GO+ 
c) Setelah login masuk ke dalam Green Orchesta Plus(GO+)

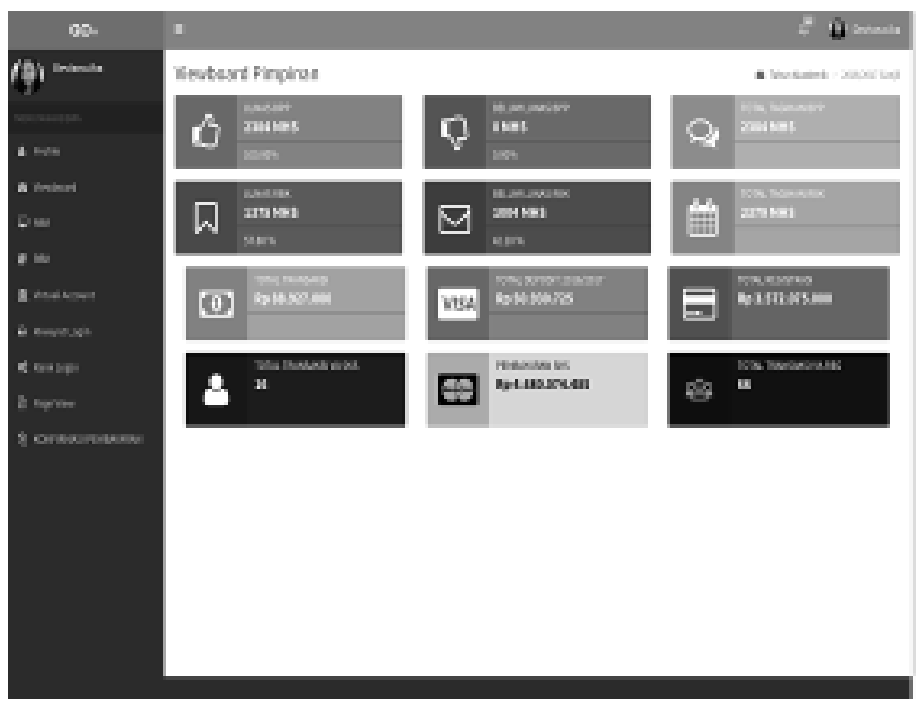

Gambar 9. Tampilan home $\mathrm{GO}+$

d) Kemudian masuk kedalam Rincian Biaya Register

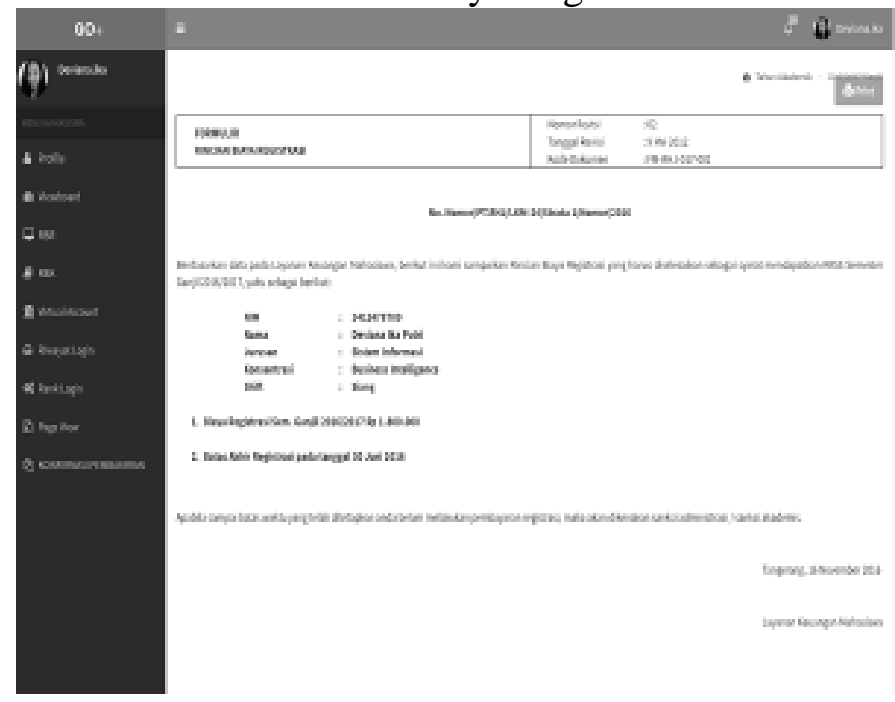

Gambar 10. Tampilan Rincian Biaya Register

e) Dibawah ini contoh Rincian Biaya Kuliah dalam Green Orchesta Plus(GO+) 


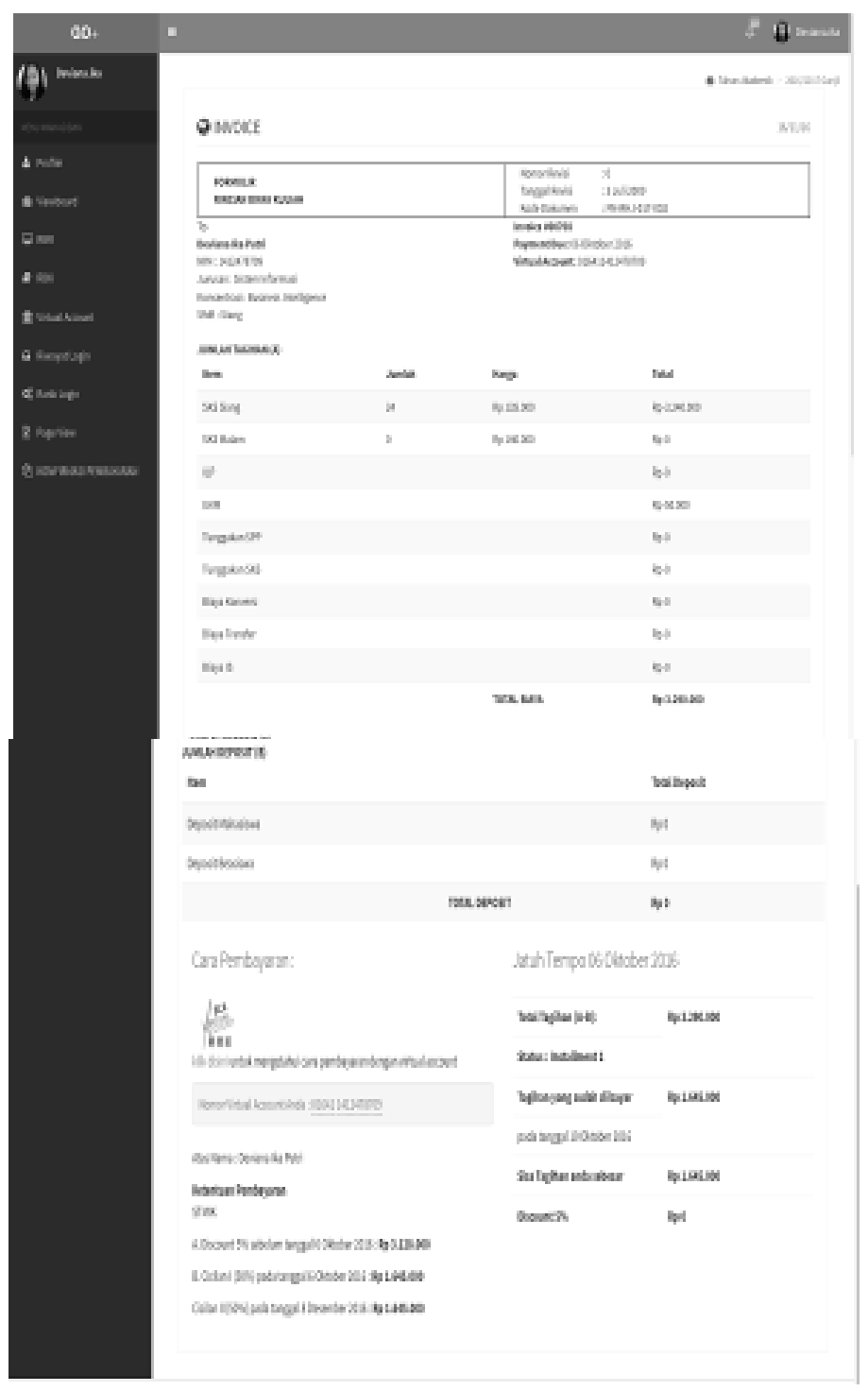

Gambar 11. Tampilan Rincian Biaya Kuliah

Adanya GO+ yang mudah diakses online maka kemudahan dan mutu pelayanan mahasiswa bisa terwujud. Pada saat mahasiswa ingin mengetahui tagihan yang harus dibayarkan, mahasiswa tidak perlu mengantri di box sis atau bertanya langsung pada kasir. Sehingga mahasiswa tidak perlu mengantri di Box Sis dan mahasiswa tidak perlu pergi ke kampus jika sedang tidak berada di kampus. Penyediaan sistem GO+ diharapkan mampu memberikan kemudahan bagi setiap mahasiswa Perguruan Tinggi Raharja dalam mencari informasi tagihan pembayaran perkuliahan.[5]

\section{KESIMPULAN}

Dengan adanya Green Orchesta Plus(GO+) untuk pribadi Raharja sangat bermanfaat sehingga dapat membantu mahasiswa/i lebih memudahkan dalam proses pembayaran kuliah. Pada transaksi pembayaran perkuliahan secara manual mahasiswa lebih banyak kehabisan waktu untuk melihat pembayaran jatuh tempo di BoxSIS, selain di BoxSIS mahasiswa harus mengantri pada kasir menanyakan seputar pembayaran perkuliahan namun dengan adanya site GO+ mahasiswa/i lebih efisien dan praktis dalam pembayaran. Dengan Green Orchesta Plus(GO+) 
selain mempunyai fitur - fitur yang sangat banyak, mahasiswa juga bisa langsung mengecek secara rinci pembayaran yang sudah dibayar maupun yang belum dibayar untuk melihat seluruh pembayaran jatuh tempo. Green Orchesta(GO+) ini akan sangat memudahkan staff keuangan dan kasir dalam mengetahui siapa saja mahasiswa yang sudah melakukan pembayaran. GO+ pun bisa dilakukan dimana saja dan kapan saja dengan menggunakan atau terhubung pada koneksi internet. Kemudian banyak berbagai macam tools di GO+ yang dapat menjelaskan secara detail histori dari tools yang telah mahasiswa pilih. Dalam tools tersebut juga terdapat tools yang berfungsi untuk, jika sudah membayar melalui bank dapat melampirkan foto berupa bukti tanda sudah melakukan pembayaran. Dengan adanya media pembayaran seperti GO+ informasi rincian biaya kuliah lebih akurat dan ter- up to date. Pembayaran secara online pada Perguruan Tinggi Raharja membuat mahasiswa lebih mudah dalam mengaksesnya.

\section{Daftar Pustaka}

[1] Situmorang, Romada, "Sistem Pembayaran", Pendidikan Ekonomi SMA, 2011.

[2] Waluyo, tirto, Perpajakan Indonesia, Salemba Empat: Jakarta, 2010.

[3] Hasibuan, Malayu S.P, "Manajemen Sumber Daya Manusia”, Jakarta: Bumi Aksara, 2011.

[4] Jogiyanto H.M, 1999, Analisis dan Disain Sistem Informasi, Andi, Yogyakarta.

[5] Nurhaeni, Tuti, dkk. "PENERAPAN GO+ BERBASIS ONLINE UNTUK MENINGKATKAN MUTU PELAYANAN LEMBAGA KEUANGAN MAHASISWA", jurnal: Perguruan Tinggi Raharja, 2015.

[6] Fransisca Rahardja, OOAD, Students Aggrement, 2016.

[7] Faradisa, Yeti, "Perancangan GO+ Sebagai Media Informasi Tagihan Pembyaran Perkuliahan Pada Perguruan Tinggi”, Tugas Akhir: Perguruan Tinggi Raharja, 2015. 